\title{
Study the effect of probiotic bacteria isolated from foods on pathogens.
}

\author{
Abeer Abu Zaid ${ }^{1,2 *}$ \\ ${ }^{1}$ Department of Special Food and Nutrition, Food Technology Research Institute, Agricultural Research Center, Giza, \\ Egypt \\ ${ }^{2}$ Department of Biology, Faculty of Science, Taif University, Saudi Arabia
}

\begin{abstract}
Eleven Bacillus strains were isolated from foods and evaluated their probiotic potential and safety. Then study the effect of selected strains against pathogens, and on the population of pathogens in Reconstituted Skim Milk (RSM). Seven strains from Bacillus sp. (3) and Bacillus subtilis (4) were selected which were grow in low $\mathrm{pH} 1.0$ to 5.0 and tolerant bile salt 0.3 to $2 \%$, highly resistant to simulated gastrointestinal tract conditions, and showed antimicrobial activity against Salmonella typhimurium ATCC20231 and Staphylococcus aureus ATCC25923. They had antibiotic susceptibility against 6 tested antibiotics. Also, it's exhibited non-hemolytic on sheep blood. Two pathogens were completely inhibited after 60 and $72 \mathrm{hrs}$ of incubation with selected probiotic strains in RSM. The results indicate that Bacillus subtilis or Bacillus sp. could be used as probiotic cultures for animal feeds and human, fermented vegetables, milk, meat product as well as to achieve bio preservation of dairy products in food industries.
\end{abstract}

Keywords: Probiotic strains, Bacillus sp., Antibacterial, Antibiotic, Gastrointestinal tract conditions.

Accepted on February 26, 2018

\section{Introduction}

Food borne illness is major international health problem in worldwide and it reduced the economic growth, although enhanced performance of effective legislative control on food processing procedures in industries [1]. Food borne diarrheal diseases are causes of illness and death 2.2 million people annually and over than 200 types of illness transmitted by food [2,3]. These pathogens are Listeria monocytogenes, Staphylococcus aureus, Escherichia coli, Salmonella typhi., Bacillus cereus, yeasts and moulds. The use of naturally produced anti-microbial agents without any adverse effects on human health to inhibit the propagation of pathogenic microorganisms in foods, that is may be challenge the problems associated with food contamination.

The expression of "probiotics" was plagiaristic from the Greek word, it is meaning as "for life" [4]. After that, defined probiotics as: "Live microorganisms" which when administered in sufficient amounts confer a beneficial health to host by improving its microbial balance in gut [5,6]. Probiotic bacteria may be producing various Anti-microbial metabolites, which include organic acids (lactic and acetic acids), and bacteriocins. The organic acids not only lower the $\mathrm{pH}$, but they can also be toxic to the pathogens. The beneficial of probiotic bacteria are prevention and treatment of diseases in gastrointestinal disturbances, such as dysentery, diarrhoea, typhoid [7].
Lactobacillus, Bifidobacterium, Lactococcus, Leuconostoc, Bacillus and many others are integrated in the list of probiotics [8]. Probiotics are well recognized to possess specific properties such as; gastric juice and bile tolerance, adhesion to the epithelial cells of the intestine, survive in the gastrointestinal tract of humans and animals and improvement of the intestinal microbial balance [9].

Probiotics bacteria, like common microorganisms, it may possess undesirable properties such as the advent of harmful biochemical and virulence factors. They are non-spore former, and may be destroyed in high bile concentrations of the duodenum and stomach acids. Therefore, large numbers from probiotics bacteria were require surviving in the gut anaerobic. To challenge this problem, many studies are in progress on the applicability of a new spore forming Bacilli probiotics, such as; Bacillus coagulans, Bacillus subtilis, Bacillus licheniformis, Bacillus polymyxa, and Bacillus mesentricus. They are non-pathogenic and naturally found in water and soil, ferment a large number of sugars, secrete protease, lipase and amylase enzymes, survive in the stomach and reach the intestine to germinate, and thermo stable.

Bacillus species are Gram positive bacilli, produce heat resistant spores and widespread in environment or many types of food. B. subtilis is not harmful to mammals, including humans, and is commercially important as producer of a high fine chemicals and enzymes and diverse amount of secondary metabolites like antibiotics, as well as heterologous proteins, 
antigens and vaccines [7,10,11]. B. subtilis grow efficiently with low-cost carbon and nitrogen sources, because its enzymes are very efficient breaking down a great variety of proteins, carbohydrates and lipids from animal and vegetable origin, into their constituent units [12]. B. subtilis spores have the ability to resist extreme $\mathrm{pH}$ conditions, UV irradiation, high temperatures, solvents and long time periods of storage without refrigeration [13]. In review, B. subtilis has adaptability of growth nutrients utilization, production high level of enzymes, secretion of antimicrobial compounds, develops in aerobic and anaerobic conditions, and B. subtilisis Generally Recognized as Safe (GRAS) by the Food and Drug Administration (FDA). Finally, B. subtilis in "theory" may be well measured as an ideal multifunctional probiotic bacterium for hosts [11,14-17].

The aim of this study is to evaluate the potential probiotics properties of Bacillus bacteria isolated from food, and their antibacterial effects against pathogenesis. Finally, study the effect of co-culturing probiotic bacteria with pathogenic in skim milk.

\section{Material and Methods}

\section{Bacterial strains}

Eleven bacterial strains (M01-M11) were isolated under aerobic conditions from twelve traditional food products; further all strains were identified by partial 16SrRNA gene sequencing and phylogenetic analysis. All strains were identified by $97-100 \%$ identity including Bacillus circulance (4), Bacillus sp. (3) and Bacillus subtilis (4), according to Zaid [18]. Standard biochemical tests such as gram reaction, spore former, motility, catalase reaction, oxidase activity, Esculin hydrolysis were performed following standard assessment [19].

\section{Probiotic potential}

pH tolerance: The isolates were inoculated into sterile Nutrient Broth (NB) tubes of varying pH, i.e. 1,2, 3, 4, and 5 incubated at $37^{\circ} \mathrm{C}$ for $24 \mathrm{~h}$. Then $0.1 \mathrm{ml}$ inoculums from each tube was poured as nutrient agar medium by pour plate method and incubated at $37^{\circ} \mathrm{C}$ for $48 \mathrm{~h}$. The growth of bacteria on agar was used to designate isolates as $\mathrm{pH}$ tolerant [7].

\section{Bile salt tolerance}

The medium with varying concentrations of bile salt $(0.3,0.5$, $1.0,2.0,3.0$ and 4.0\%) was inoculated with each selected bacterial culture and incubated at $37^{\circ} \mathrm{C}$ for $48 \mathrm{~h}$. Then $0.1 \mathrm{ml}$ inoculums was transferred to nutrient agar by pour plate method and incubated at $37^{\circ} \mathrm{C}$ for $48 \mathrm{~h}$. The growth of bacteria on agar plate was used to designate isolates as bile salt tolerant [7].

\section{Hemolytic activity}

For testing haemolytic activity, isolates were streaked on Columbia agar plates; containing 5\% (w/v) sheep blood [20].

\section{Antibiotic susceptibility}

The selected Bacillus strains were evaluated for antibiotic susceptibility by using agar diffusion method on Mueller Hinton agar [21]. Antibiotics such as ampicillin (Am $10 \mathrm{U}$ ); penicillin (P $10 \mathrm{mg}$ ); nalidixic acid (NA, $30 \mu \mathrm{g}$ ); vancomycin $(\mathrm{V}, 30 \mu \mathrm{g})$; colistin $(\mathrm{CS}, 10 \mu \mathrm{g})$; tetracycline $(\mathrm{T}, 10 \mu \mathrm{g})$; Gentamicin (GM, $10 \mathrm{mg}$ ); Fusidic acid (FA, $10 \mathrm{U}$ ).All antibiotics were purchased from Bio-Rad, Laboratories, $\mathrm{GmbH}$., Germany. Isolates culture suspension containing $\sim 10^{6}$ $\mathrm{cfu} / \mathrm{mL}$ of the $18 \mathrm{~h}$ culture at $37^{\circ} \mathrm{C}$, then streaked on agar by a sterile cotton swab. The studied antibiotic discs were aseptically placed on the plates. The diameters of inhibition zone were calculated in $\mathrm{mm}$ under the colony counter after 24 $\mathrm{h}$ of incubation.

\section{Effect of simulated gastrointestinal conditions}

According to Zago et al., simulated gastrointestinal conditions were designed [1]. The growth of isolates at $\mathrm{pH} 2.0$ in the presence of $1 \%$ lysozyme, $1 \%$ trypsin, and $0.3 \%$ bile slat in Tryptic Soy Broth (TSB) was used to designate isolates as simulated gastrointestinal conditions.

\section{Antimicrobial activity}

For detection of antagonism activity, an agar spot test was used [22]. Overnight cultures, on NB medium, of the strains to be tested for production of antimicrobial compound were centrifuged $\left(10 \mathrm{~min}\right.$ at $\left.15000 \mathrm{~g}, 4^{\circ} \mathrm{C}\right)$. Cell-free supernatants were filtered across cellulose acetate filter $(0.2 \mu \mathrm{m})$ to remove residual cells. An overnight culture $\left(37^{\circ} \mathrm{C}\right)$ of the target strain was diluted in sterile Mueller-Hinton Medium, and $1 \mathrm{~mL}$ of $10^{6} \mathrm{CFU}$ was spread on solid Mueller-Hinton medium. The petri dishes were dried for $10 \mathrm{~min}$. Cork borer was used to punch one hole, $4.1 \mathrm{~mm}$ in diameter. Nutrient agar was used to seal the bottom of holes. Samples $(30 \mu \mathrm{L})$ of filtered cell-free supernatants were transferred on the agar plate. The target strains used in this study are Salmonella typhimurium ATCC20231, and Staphylococcus aureus ATCC25923.

\section{Effect of co-culturing probiotic bacteria with pathogenic}

This method was used to study the effect of probiotic bacteria on the population of pathogenic in reconstituted skim milk (RSM). $9 \mathrm{~mL}$ of RSM was inoculated with $1 \mathrm{~mL}$ overnight culture of probiotic bacteria and $0.1 \mathrm{~mL}$ of pathogenic. Inoculated RSM medium was mixed well and incubated at $37^{\circ} \mathrm{C}$ for $0,12,24,36,48,60,72 \mathrm{~h}$. Following incubation, the population of spoilage and pathogenic bacteria was counted on nutrient agar [23].

\section{Statistical analysis}

The data obtained from treatments were analyzed by one-way ANOVA using 'Proc Mixed' (SAS 8.2, Cary, NC, USA). In all cases, the level of statistical significance was of $\mathrm{P}<0.05$. SAS program was used to statistical analyzed (SAS 2001); LSD 
means comparisons were conducted with the Duncan option in SAS.

\section{Results and Discussion}

Eleven bacterial strains (M1-M11) were isolated from foods under aerobic condition characterized by biochemical conditions then identified by partial 16SrRNA gene sequencing and phylogenetic analysis by Zaid et al. [18]. Eleven strains were identified by $97-100 \%$ identity including Bacillus circulance (4), Bacillus subtilis (4), Other isolates were identified by $85-92 \%$ identity; therefore these species are considered as new ones and named: Bacillus sp. (M07, M08, M10). Cutting identified Bacillus strains as probiotic, they were B. subtilis, B. coagulans, B. cereus and B. clausii [14]. Recently, Manhar et al. also introduced B. amyloliquefaciens as potential probiotics [24]. Probiotic bacillus strains can produce spores under insensitive conditions such as high heat, low $\mathrm{pH}$, dry, and worn out nutrients, which bacterial cells cannot stay alive, and remain viable till exposed to more good conditions. This provides many opportunities for probiotic Bacillus sp. over non-spore forming bacteria such as Lactobacillus, and Bifido bacterium strains. Spore forming probiotic bacillus strains are widely used as nutritional supplements in humans, increase shelf life of dairy products and as growth promoters in animals and fish [14].
Bacillus subtilis and Bacillus sp. strains showed significant differences antimicrobial effect against two tested pathogenic strains, but Bacillus circulan strains exhibited no activity against pathogens as shown in Table 1. On the basis of maximum zone scored by M6 against Salmonella typhimurium and Staphylococcus aureus were $28 \mathrm{~mm}$ and $25 \mathrm{~mm}$ respectively.

The same finding, Patel et al. reported that, the probiotic Bacillus strain DET6 isolated from food wastes inhibited growth of Salmonella typhi and E. coli [25]. Mahdhi et al. selected probiotic Bacillus strains had an antibacterial activity against Gram-positive and Gram-negative bacteria with diameter of the inhibition zones range between $12 \mathrm{~mm}$ and $18.6 \mathrm{~mm}$ [26]. Lee et al., isolated and identified three probiotic Bacillus strains from Korean traditional soy sauces, and showed antimicrobial activity against Bacillus cereus, Listeria monocytogenes, Staphylococcus aureus and Escherichia coli [27]. On the other hand, B. amyloliquefaciens did not show any affect against B. cereus, Yersinia enterocolitica and Salmonella typhimurium, but inhibited the growth of L. monocytogenes and K. pneumoniae reported by Manhar et al. [24].

Table 1. Inhibition zone of selected probiotic isolates against some foodborne pathogens.

\begin{tabular}{|c|c|c|c|}
\hline & \multirow{2}{*}{ Probiotic bacteria } & \multicolumn{2}{|c|}{ Diameter of inhibition zone $(\mathrm{mm})$ by pathogenic bacteria } \\
\hline & & Salmonella typhimurium & Staphylococcus aureus \\
\hline M1 & Bacillus circulan & $N A^{b}$ & $N A^{b}$ \\
\hline M2 & Bacillus subtilis & $25^{a}$ & $20^{\mathrm{a}}$ \\
\hline M3 & Bacillus circulan & $N A^{b}$ & $N A^{b}$ \\
\hline M4 & Bacillus subtilis & $26^{a}$ & $22^{\mathrm{a}}$ \\
\hline M5 & Bacillus subtilis & $27^{a}$ & $19^{a}$ \\
\hline M6 & Bacillus subtilis & $28^{a}$ & $25^{a}$ \\
\hline M7 & Bacillus sp. & $26^{a}$ & $20^{\mathrm{a}}$ \\
\hline M8 & Bacillus sp. & $20^{\mathrm{a}}$ & $15^{\mathrm{a}}$ \\
\hline M9 & Bacillus circulan & $N A^{c}$ & $N A^{b}$ \\
\hline M10 & Bacillus sp. & $22^{\mathrm{a}}$ & $18^{a}$ \\
\hline M11 & Bacillus circulan & $N A^{c}$ & $N A^{b}$ \\
\hline L.S.D & & 10.6 & 9.63 \\
\hline
\end{tabular}

a,b,cMeans within arrow for insect pest followed by different letters are significantly different $(P<0.05$; using Duncan's multiple range; NA: No Activity.

Probiotic potential of selected spore former Bacillus strains $\mathrm{pH}$ and Bile salt tolerance were shown in Table 2. In this study, Bacillus subtilis and Bacillus sp. strains were able to grow in $\mathrm{pH}$ from 1.0 to 5.0 and survive in bile salt concentrations from 0.3 to $2 \%$. Bacillus circulan strains were lost their tolerance to low acidity at $\mathrm{pH} 1.0,2.0$ and 3.0 and all bile salt concentrations. On other hand, probiotic bacteria isolated from baobab (maari) fermented seeds could tolerate bile salt concentration of $0.3 \%$, and able to survive at $\mathrm{pH} 2.5$ [28]. Tambekar et al. isolated probiotic, which tolerance to acid $(\mathrm{pH}$ 2.0) and bile salt at $2.0 \%$ [7]. Tolerance to bile salts is a requirement for colonization and metabolic activity of bacteria in the small intestine of the host [29]. This will help probiotic 
bacteria to reach the small intestine and colon and contribute in balancing the intestinal microflora [7].

Table 2. pH and bile salt tolerance of selected probiotic isolates.

\begin{tabular}{|c|c|c|c|c|c|c|c|c|c|c|c|c|}
\hline & \multirow[t]{2}{*}{ Isolate no. } & \multicolumn{5}{|c|}{$\begin{array}{l}\text { Growth after } \\
\text { exposure to pH (PH } \\
\%)\end{array}$} & \multicolumn{6}{|c|}{$\begin{array}{l}\text { Growth in the presence of } \\
\text { bile salt (\%) }\end{array}$} \\
\hline & & 1 & 2 & 3 & 4 & 5 & 0.3 & 0.5 & 1 & 2 & 3 & 4 \\
\hline M1 & Bacillus circulan & - & - & - & + & + & - & - & - & - & - & - \\
\hline M2 & Bacillus subtilis & + & + & + & + & + & + & + & + & + & - & - \\
\hline M3 & Bacillus circulan & - & - & - & + & + & - & - & - & - & - & - \\
\hline M4 & Bacillus subtilis & - & + & + & + & + & + & + & + & + & - & - \\
\hline M5 & Bacillus subtilis & + & + & + & + & + & + & + & + & + & - & - \\
\hline M6 & Bacillus subtilis & + & + & + & + & + & + & + & + & + & - & - \\
\hline M7 & Bacillus sp. & - & + & + & + & + & + & + & + & + & - & - \\
\hline M8 & Bacillus sp. & - & + & + & + & + & - & - & - & - & - & - \\
\hline M9 & Bacillus circulan & - & - & - & + & + & + & + & + & + & - & - \\
\hline M10 & Bacillus sp. & + & + & + & + & + & + & + & + & + & - & - \\
\hline M11 & Bacillus circulan & - & - & - & + & + & - & - & - & - & - & - \\
\hline
\end{tabular}

\section{Antibiotic susceptibility test}

The antibiotic resistances of the probiotic Bacillus strains were tested by using two groups of antibiotics categorized by their mechanisms. The first one was cell wall inhibitors including ampicillin, penicillin $\mathrm{G}$ and vancomycin, and second group were protein synthesis inhibitors including gentamicin and tetracycline [30]. Bacillus subtilis and Bacillus sp. strains were scored multi drug resistance against 6 types of antibiotics. Antibiotic susceptibility is measured to be the best probiotic characteristic [25]. In this study Bacillus subtilis and Bacillus $s p$. strains also showed the highest resistance to ampicillin and penicillin G (Table 3). This is parallel to the reports by Manhar et al. [24]. They reported that B. amyloliquefaciens AMS1 were resistant to ampicillin and penicillin and probiotic Bacillus sp.

Table 3. Antibiotic resistance profile index of the selected probiotic strains.

\begin{tabular}{|c|c|c|c|c|c|c|c|c|c|}
\hline $\begin{array}{l}\text { Isolat } \\
\text { e no. }\end{array}$ & $\begin{array}{l}\text { P } 10 \\
\text { mg }\end{array}$ & $\begin{array}{l}A M \\
10 U\end{array}$ & $\begin{array}{l}\text { CS } 10 \\
\mu g\end{array}$ & $\begin{array}{l}\text { FA } \\
10 \mathrm{U}\end{array}$ & $\begin{array}{l}\mathrm{GM} \\
10 \mathrm{mg}\end{array}$ & $\begin{array}{l}\text { NA } 30 \\
\mu \mathrm{g}\end{array}$ & $\begin{array}{l}\text { V } 30 \\
\mu \mathrm{g}\end{array}$ & $\begin{array}{l}\mathrm{T} 10 \\
\mu \mathrm{g}\end{array}$ & $\begin{array}{l}\text { No. of } \\
\text { antibiotic } \\
\text { resistanc } \\
\text { e }\end{array}$ \\
\hline M1 & - & - & $\mathrm{R}$ & - & - & $\mathrm{R}$ & - & - & 2 \\
\hline M2 & $\mathrm{R}$ & $\mathrm{R}$ & $\mathrm{R}$ & - & $\mathrm{R}$ & - & $\mathrm{R}$ & 1 & 6 \\
\hline M3 & - & - & - & - & - & $\mathrm{R}$ & - & - & 1 \\
\hline M4 & $\mathrm{R}$ & $\mathrm{R}$ & & & $\mathrm{R}$ & $\mathrm{R}$ & $\mathrm{R}$ & I & 6 \\
\hline M5 & $\mathrm{R}$ & $\mathrm{R}$ & - & - & $\mathrm{R}$ & 1 & $\mathrm{R}$ & $\mathrm{R}$ & 6 \\
\hline
\end{tabular}

\begin{tabular}{llllllllll}
\hline M6 & $\mathrm{R}$ & $\mathrm{R}$ & $\mathrm{R}$ & & $\mathrm{R}$ & $\mathrm{R}$ & $\mathrm{I}$ & 6 \\
\hline $\mathrm{M} 7$ & $\mathrm{R}$ & $\mathrm{R}$ & $\mathrm{R}$ & - & $\mathrm{R}$ & $\mathrm{I}$ & - & $\mathrm{R}$ & 6 \\
\hline $\mathrm{M} 8$ & $\mathrm{R}$ & $\mathrm{R}$ & - & - & $\mathrm{R}$ & $\mathrm{R}$ & $\mathrm{R}$ & $\mathrm{I}$ & 6 \\
\hline $\mathrm{M} 9$ & - & - & $\mathrm{R}$ & - & - & - & - & - & 1 \\
\hline $\mathrm{M} 10$ & $\mathrm{R}$ & $\mathrm{R}$ & $\mathrm{R}$ & - & $\mathrm{R}$ & $\mathrm{R}$ & - & $\mathrm{I}$ & 6 \\
\hline $\mathrm{M} 11$ & - & - & - & - & - & $\mathrm{I}$ & - & $\mathrm{I}$ & 2
\end{tabular}

Inhibition zone diameters were determined general of the diameter of the discs. (-) Sensitive ( $\geq 21 \mathrm{~mm})$; I: Intermediate $(16-20 \mathrm{~mm})$; R: Resistant $(\leq 15 \mathrm{~mm})$; AM: Ampicillin; CS: Colistin; FA: Fusidic Acid; GM: Gentamicin; NA: Nalidixic Acid; P: Pencillin; V: Vancomycin; T: Tetracycline.

\section{Hemolytic activity}

One of the main criteria needed to be satisfied by a probiotic organism is to be non-pathogenic [31]. In general, it can be noticed that no strain observed complete hydrolysis $(\beta$ hemolysis) on blood sheep agar. Other isolated strains 7 out of 11 observed no hemolytic activity ( $\gamma$ hemolysis). Bacillus circulan strains displayed greenish-brown color ( $\alpha$ hemolysis) around their colonies grown on blood sheep agar (Table 4). This study was comparable to probiotic $B$. polyfermenticus CJ6; it was observed no hemolytic activity [32]. Probiotic Bacillus sp. BCNU9028 formed a green zone that indicates $\alpha$ hemolysis. $B$. cereus produces a clear zone that indicates $\beta$ hemolysis [32]. No-hemolysis and a-hemolysis are considered to be safe and $\beta$-hemolysis was considered harmful [33]. $\beta$ hemolysis is an implication that bacteria have cytotoxic phospholipases [4]. The hemolytic factor decreases the amount of hemoglobin available as an iron source for the host [34].

Table 4. Hemolytic activity of the selected probiotics strains.

\begin{tabular}{lll}
\hline Strains & Growth on blood sheep agar & Type of hemolysis $^{*}$ \\
\hline M1 & Green-hued zones around colonies & $\alpha$ \\
\hline M2 & No zones around colonies & Y \\
\hline M3 & Green-hued zones around colonies & $\alpha$ \\
\hline M4 & No zones around colonies & Y \\
\hline M5 & No zones around colonies & Y \\
\hline M6 & No zones around colonies & Y \\
\hline M7 & No zones around colonies & Y \\
\hline M8 & No zones around colonies & Y \\
\hline M9 & Green-hued zones around colonies & $\alpha$ \\
\hline M10 & No zones around colonies & Y \\
\hline M11 & Green-hued zones around colonies & $\alpha$ \\
\hline
\end{tabular}

${ }^{*}$ Hemolytic activity was described as no $(\gamma)$, incomplete $(\alpha)$ and complete $(\beta)$ hemolysis.

To select the probiotics strains with high probiotic potential, simulate gastrointestinal conditions by identified strains were grow in the presence bile salt, lysozyme, and trypsin at low $\mathrm{pH}$. If the tested strains have ability to grow under these 
environmental stresses, these bacterial strains can tolerant, adhere, colonize and grow after transit from the stomach to small intestinal. In the present study, all isolated strains were studied in the presence of $1.0 \%$ lysozyme, $1.0 \%$ trypsin and $0.3 \%$ bile slat at $\mathrm{pH} 2.0$. Most studied strains 7 out of 11 were could be grow under simulate gastrointestinal conditions.

In conclusion, the effect of trypsin and lysozyme might be avoided due to not fitting $\mathrm{pH}$, where these enzymes could be inactivated at low temperature and optimal $\mathrm{pH}$ 7.5-8.5 [35]. Lysozyme activity was significantly decreased at $\mathrm{pH} 6.2$ or below [36]. After this explanation, the most effective factors in this simulated gastrointestinal were bile salt and $\mathrm{pH}$. As described above, the obtained results demonstrated that, bile slat and low $\mathrm{pH}$ induced adherent and biofilm formation due to increasing cell hydrophobicity [1,37-41].

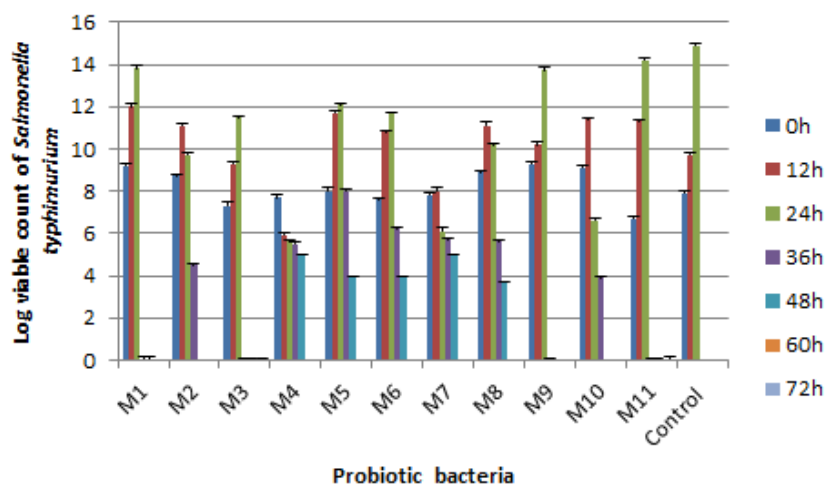

Figure 1. Effect of co-culturing with probiotic bacteria in reconstituted skim milk media on log population of Salmonella typhimurium.

Experimental results, given in Figures 1 and 2, were shown that the effect of probiotic Bacillus strains on the population of pathogens in Reconstituted Skim Milk (RSM). It depends on the variety of the pathogen as well as of the types of Bacillus probiotic strains. The agent of Salmonella was sensitive to the presence of Bacillus subtilis and Bacillus sp. strains during all the period of incubation; it was complete inhibition up to the $60^{\text {th }} \mathrm{h}$.

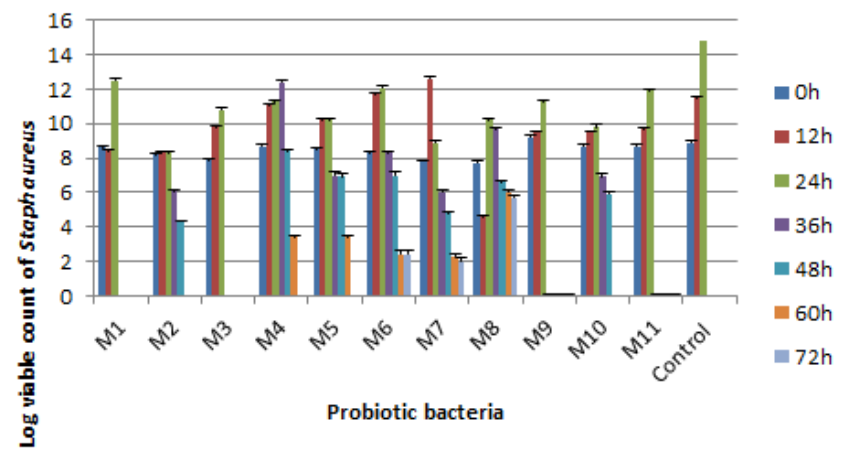

Figure 2. Effect of co-culturing with probiotic bacteria in reconstituted skim milk media on log population of Staphylococcus aureus.

Staphylococcus aureus was more resistant in the presence of Bacillus subtilis and Bacillus sp., it completely inhibited after
$72 \mathrm{~h}$ of incubation period. Bacillus circulan strains have a similar behavior of control as shown from results and spoilage all samples after $48 \mathrm{~h}$ of incubation periods. The same finding by Denkova et al. concluded that E. coli and Salmonella were sensitive to the presence of probiotic bacteria and during joint cultivation complete inhibition up to the $60^{\text {th }}$ to the $72^{\text {nd }} \mathrm{h}$ of incubation [23]. On the other contrasting, Staphylococcus aureus showed more resistant to the presence of probiotic bacteria in the medium, but this pathogen was sensitive to Bif. Bifidum strain only.

In conclusion, seven strains (4 Bacillus subtilis and 3 Bacillus $s p$.) showed no hemolytic activity ( $\gamma$ hemolysis), antibacterial activity, tolerated low $\mathrm{pH} 2.0$, bile salt up to $0.3 \%$; viable under Stimulated Gastrointestinal Tract (SGIT) stress. These strains are strongly suggested to use as probiotics and can be measured as generally recognized as safe (GRAS) bacteria. The other four strains from Bacillus circulan have ability to incomplete hemolysis ( $\alpha$ hemolysis) and lost one of the important criteria (acid and bile tolerance). Therefore its need to advance work to assess their safety to use as probiotics. It could be concluded on the combine of different probiotic strains in order to complete the inhibition growth of bacteria and spores. As a result of the conducted studies strains of Bacillus subtilis and Bacillus sp. had high antimicrobial activity, it's important for the application of these probiotic strains in foods to extend the shelf life. Bacillus probiotics strains were used for the production of functional foods (yogurt; bioyogurt; bread with extended shelf-life; raw-dried meat products; cheeses; organic preservation of cosmetic creams).

\section{References}

1. Zago M, Fornasari ME, Carminati D, Burns $P$, Suàrez V, Vinderola G, Reinheimer J, Giraffa G. Characterization and probiotic potential of Lactobacillus plantarum strains isolated from cheeses. Food Microbiol 2011; 28: 1 033-1040.

2. Lynch M, Painter J, Woodruf, Brade C. Surveillance for foodborne disease outbreaks-United States 1998-2002. MMWR. Surveillance summaries: morbidity and mortality weekly reported. Surveillance Summaries/DC 2006; 55: 1-42.

3. Mensah P, Yeboah-Manu D, Owusu-Darku K, Ablordey A. Street food in Accra, Ghana: How safe are they? Bulletin of the World Health Organization 2002; 80: 546-556.

4. Reid G, Hass J, Sebulsdy MT, McCormick JD. Potential use of probiotics in clinical practice. Clin Microbiol Rev 2003; 16: 658-672.

5. Aslam S, Qazi JI. Isolation of acidophilic lactic acid bacteria antagonistic to microbial contaminants. Pak J Zool 2010; 42: 567-573.

6. FAO/WHO. Probiotic in foods: Health and nutritional properties and guidelines for evaluation. In FAO Food Nutrition 2005; 85. 
7. WHO. Food safety and foodborne illness. World Health Organization 2007.

8. Isolauri E, Salminen S, Ouwehand AC. Probiotics. Best Pract Res Clin Gastroenterol 2004; 18: 299e313.

9. MFDS. Ministry of Food and Drug Safety: Safe food \& drugs, healthy people happy society. Republic of Korea 2015.

10. Bérdy J. Bioactive microbial metabolites. J Antibiot (Tokyo) 2005; 58: 1-26.

11. Ochoa SJL. Functional feeds with high soy flour, starch and bacillus spp content. US Patent Application Publication 2012.

12. Sonnenschein AL, Losick R, Hoch JA. Bacillus subtilis and others gram-positive bacteria: biochemistry, physiology and molecular genetics. Am Soc Microbiol 2013.

13. Cutting SM. Bacillus probiotics. Food Microbiol 2011; 28: $214-220$.

14. Huang Q, Xu X, Mao YL, Huang Y, Rajput IR. Effects of Bacillus subtilis B10 spores on viability and biological functions of murine macrophages. Anim Sci J 2013; 84: 247-252.

15. Olmos J, Ochoa L, Paniagua-Michel J, Contreras R. Functional feed assessment on Litopenaeusvannamei using $100 \%$ fish meal replacement by soybean meal, high levels of complex carbohydrates and Bacillus probiotic strains. Mar Drugs 2011; 9: 1119-1132.

16. Sorokulova I. Modern status and perspectives of Bacillus bacteria as probiotics. J Prob Health 2013; 1: 1-5.

17. Abu-Zaid AA. Influence of spirulina platensis cyanobacterium on some pathogenic bacteria isolated from different diets. Int J Sci Res 2015; 2.

18. Cappuccino JG, Sherman N. Microiology: A laboratory manual. Pearson Education 1999; 4: 199-204.

19. Ghrairi T, Frere J, Berjeaud JM, Manai M. Purification and characterisation of bacteriocins produced by Enterococcus faecium from Tunisian rigouta cheese. Food Control 2008; 19: 162-169.

20. Bauer AW, Kirby WM, Sherris JC, Turck M. Antibiotic susceptibility testing by a standardized single disk method. Am J Clin Pathol 1966; 36: 49-52.

21. Mezaini A, Chihib NE, Bouras AD, Nedjar-Arroume N, Hornez JP. Antibacterial activity of some lactic acid bacteria isolated from an Algerian dairy product. J Environ Pub Health 2009.

22. Denkova R, Denkova Z, Yanakieva V, Blazheva D. Antimicrobial activity of probiotic lactobacilli, bifidobacteria and propionic acid bacteria, isolated from different sources. Rositsa Denkova Univ Food Technol 2013; 867-864.

23. Manhar AK, Saikia D, Bashir Y, Mech RK, Nath D, Konwar BK. In vitro evaluation of celluloytic Bacillus amyloliquefaciensAMS1 isolated from traditional fermented soybean (Churpi) as an animal probiotic. Res Veterinary Sci 2015; 99: 149e156.
24. Patel AK, Ahire JJ, Pawar SP, Chaudhari BL, Chincholkar SB. Comparative accounts of probiotic characteristics of Bacillus spp. isolated from food wastes. Food Res Int 2009; 42: 505e510.

25. Mahdhi A, Kamoun F, Messina C, Santulli A, Bakhrouf A. Probiotic properties of Brevibacillus brevis and its influence on sea bass (Dicentrarchus labrax) larval rearing. Afr J Microbiol Res 2012; 6: 6487-6495.

26. Lee S, Lee J, Jin YI, Jeong JC, Chang YH, Lee Y, Jeong Y, Kim M. Probiotic characteristics of Bacillus strains isolated from Korean traditional soy sauce LWT-Food Sci Technol 2017; 79: 518-524.

27. Kabore D, Sawadogo-Lingani H, Dicko MH, Diawara B, Jakobsen M. Acid resistance, bile tolerance and antimicrobial properties of dominant lactic acid bacteria isolated from traditional "maari" baobab seeds fermented condiment. Afr J Biotechnol 2012; 11: 1197-1206.

28. Havenaar R, Brink BT, Huis In't Veld JHJ. Selection of strains for probiotics use. Chappman \& Hall, London 1992; 209-223.

29. Argyri AA, Zoumpopoulou G, Karatzas KAG, Tsakalidou E, Nychas GE, Panagou EZ. Selection of potential probiotic lactic acid bacteria from fermented olives by in vitro tests. Food Microbiol 2013; 33: 282e291.

30. Ljungh A, Wadström T. Lactic acid bacteria as probiotics. Curr Issues Intestinal Microbiol 2006; 7: 73-90.

31. Jung JH, Chang HC. Evaluation of the probiotic potential of Bacillus polyfermenticus CJ6 isolated from meju, a Korean soybean fermentation starter. J Microbiol Biotechnol 2012; 22: 1510-1517.

32. Shin HJ, Choi HJ, Kim DW, Ahn CS, Lee YG, Jeong YK. Probiotic potential of pediococcuspentosaceus BCNU 9070. J Life Sci 2012; 22: 1194e1200.

33. Seker E. Identification of Candida species isolated from bovine mastitic milk and their in vitro hemolytic activity in Western Turkey. Mycopathologia 2010; 169: 303e308.

34. Barrett AJ, McDonald JK. Mammalian proteases: A glossary and bibliography (Volume 1). Endopeptidases, Academic Press, London 1980.

35. Davies RC, Neuberger A, Wilson BM. The dependence of lysozyme activity on $\mathrm{pH}$ and ionic strength. Biochimica et Biophysica Acta 1969; 178: 294-305.

36. Ambalam P, Kondepudi KK, Nilsson I, Wadström T, LjunghA. Bile stimulates cell surface hydrophobicity, Congo red binding and biofilm formation of Lactobacillus strains. FEMS Microbiol Lett 2012; 333: 10-19.

37. Nostro A, Cellini L, Di Giulio M, D' Arrigo M, Marino A, Blanco AR, Favaloro A, Cutroneo G, Bisignano G. Effect of alkaline $\mathrm{pH}$ on staphylococcal biofilm formation. APMIS 2012; 120: 733-742.

38. Olmos SJ, Paniagua-Michel J, Lopez L, Ochoa SL. Functional feeds in aquaculture. Handbook of Marine Biotechnology 2014; 1800.

39. SAS. User's guide. SAS Institute, Cary, North Carolina 2001. 
40. Sorokulova IB, Pinchuk IV, Denayrolles M, Osipova IG, Huang JM, Cutting, SM. The safety of two Bacillus probiotic strains for human use. Digest Dis Sci 2008; 8: 1-6.

41. Valdez A, Yepiz-Plascencia G, Ricca E, Olmos J. First Litopenaeus vannamei WSSV $100 \%$ oral vaccination protection using CotC: Vp26 fusion protein displayed on Bacillus subtilis spores surface. J Appl Microbiol 2014; 117: 347-357.
*Correspondence to

Abeer Abu Zaid

Department of Biology

Faculty of Science

Taif University

Saudi Arabia 